\title{
The Effect of Nitrogen and Phosphorus Ratios and Electrical Conductivity on Plant Growth
}

\author{
Laura Wiser, Theo J. Blom \\ Department of Plant Agriculture, University of Guelph, Guelph, Canada \\ Email: tblom@uoguelph.ca
}

Received 11 May 2016; accepted 16 August 2016; published 19 August 2016

Copyright (C) 2016 by authors and Scientific Research Publishing Inc.

This work is licensed under the Creative Commons Attribution International License (CC BY).

http://creativecommons.org/licenses/by/4.0/

(c) (i) Open Access

\begin{abstract}
Environmental concerns surround the use of plant growth retardants (PGRs) for plant height control, and non-chemical alternatives to PGRs can be labor intensive and expensive. Macronutrient modification is a little-studied, yet potentially effective method of controlling plant height. A number of studies have suggested that phosphorus (P) limitation may restrict plant height. Anecdotal evidence also suggests that using nitrate $\left(\mathrm{NO}_{3}^{-}\right)$, rather than ammonium $\left(\mathrm{NH}_{4}^{+}\right)$, as the principal nitrogen ( $\mathrm{N}$ ) source may help control plant height. The primary objective of this study was to evaluate different ratios of $\mathrm{NO}_{3}^{-} / \mathrm{NH}_{4}^{+}, \mathrm{NO}_{3}^{-} / \mathrm{P}$ and $\mathrm{NH}_{4}^{+} / \mathrm{P}$ as well as electrical conductivity (EC) on plant height and growth. This was tested in a hydroponic system using marigolds, sunflowers and tomatoes. Initially, different ratios were tested at an EC of $1.2 \mathrm{dS} \cdot \mathrm{m}^{-1}$, followed by using the same ratios at four ECs $\left(0.6,1.2,2.2\right.$ and $\left.4.0 \mathrm{dS} \cdot \mathrm{m}^{-1}\right)$ as a second objective. Although ratios did, at times, limit plant height, responses were season and species dependent, suggesting that modifications in plant nutrition, at the ratios used in this study, may not effectively control plant height in hydroponic systems. More consistent, yet species specific, height control was achieved by increasing EC level.
\end{abstract}

\section{Keywords}

Tagetes erecta, Helianthus annuus, Lycopersicon esculentum, Solanum lycopersicum, Plant Growth Retardants, PGR

\section{Introduction}

The use of plant growth retardants (PGRs) is becoming increasingly restricted due to environmental concerns surrounding their use. Non-chemical alternatives to PGRs, such as temperature management [1] [2], light quality 
and intensity [3] [4], mechanical stress [5], and humidity stress [6] can be labor intensive and expensive. One under evaluated potential alternative to PGR use is macronutrient management. Kavanova [7] found that supplying Lolium perenne with low phosphorous (P) levels resulted in a decrease in leaf elongation, which was attributed to a decrease in both cell division rate and cell length. Rideout [8] found similar results with tomato (Lycopersicon esculentum Mill.) seedlings.

Growers generally believe that ammonium ( $\mathrm{NH}_{4}^{+}$) may promote stem elongation compared to nitrate $\left(\mathrm{NO}_{3}^{-}\right)$. However, González-García [9] showed an opposite trend in chives (Allium schoenoprasum L.), and no effect in basil (Ocimum basilicum L.). Nelson [10] was in agreement with González-García for impatiens (Impatiens wallerana), but showed no effect for petunias (Petunia $\times$ hybrida), and showed opposite results for tomatoes and marigolds (Tagetes erecta).

Growth suppression may occur when ion concentrations increase to a point where osmotic stress, due to high electrical conductivity (EC), is induced and water availability becomes limited [11] [12]. Judd [13] found that higher fertilizer concentrations suppressed growth (plant height + width) of impatiens.

As nutrient concentrations for $\mathrm{NO}_{3}^{-}, \mathrm{NH}_{4}^{+}$and $\mathrm{P}$ also affect the EC levels, it was decided to further examine this topic. The hypothesis of this study was that modified $\mathrm{NO}_{3}^{-}, \mathrm{NH}_{4}^{+}$and $\mathrm{P}$ ratios can be used as a viable means of plant height control. This study evaluated the effects of several ratios $\left(\mathrm{NO}_{3}^{-} / \mathrm{NH}_{4}^{+}, \mathrm{NO}_{3}^{-} / \mathrm{P}\right.$, $\mathrm{NH}_{4}^{+} / \mathrm{P}$ ) on plant height. The first objective of this study was to quantify the effects of $\mathrm{NO}_{3}^{-}, \mathrm{NH}_{4}^{+}$and $\mathrm{P}$ ratios on plant height using the same total ionic strengths in solution (EC). The second objective was to evaluate the effects of these same ratios at four ECs to help establish any potential links between EC, nutrient ratio and plant height. This study was conducted in aerated nutrient solutions using 3 different species.

\section{Materials and Methods}

\subsection{Treatment Formulation}

Control treatments were based on a 1/2-strength modified Hoagland's solution \#2 [14] with an EC of approximately $1.2 \mathrm{dS} \cdot \mathrm{m}^{-1}$ (Table 1$)$. Treatment formulations were created by adjusting ionic ratios $(\mathrm{mM} / \mathrm{mM})$. To compensate for alterations in the anion/cation balance and EC, slight modifications were made to the concentrations of other ions so that all formulations provided $10 \mathrm{meq} \cdot \mathrm{L}^{-1}$ anions and $10 \mathrm{meq} \cdot \mathrm{L}^{-1}$ cations in order to obtain a similar EC.

In the first objective, $\mathrm{NO}_{3}^{-} / \mathrm{NH}_{4}^{+}$ratios were modified in a set of 7 different ratios while total $\mathrm{N}$ remained constant. To compensate for the increase in $\mathrm{NH}_{4}^{+}$levels, $\mathrm{K}^{+}, \mathrm{Ca}^{2+}$ and $\mathrm{SO}_{4}^{2-}$ concentrations were adjusted so that $\mathrm{K}^{+} / \mathrm{Ca}^{2+}$ ratios remained the same. $\mathrm{NO}_{3}^{-} / \mathrm{P}$ ratios were modified with either $\mathrm{NO}_{3}^{-}$being constant, or $\mathrm{P}$ being constant (Table 1).

Similarly, $\mathrm{NH}_{4}^{+} / \mathrm{P}$ ratios were modified with either a constant $\mathrm{NH}_{4}^{+}$or a constant $\mathrm{P}$ concentration. In the second objective, ratios from objective \#1 were repeated at EC's of $0.6,1.2,2.2$ and $4.0 \mathrm{dS} \cdot \mathrm{m}^{-1}$. The following ratios were used (mM/mM): 10, 15, 20, 30 and 60 for $\mathrm{NO}_{3}^{-} / \mathrm{P} ; 1,1.5,2.0,3.0$ and 4.0 for $\mathrm{NH}_{4}^{+} / \mathrm{P}$ and 3.25, 4.7, 7.5, 16.0 and $\infty$ for $\mathrm{NO}_{3}^{-} / \mathrm{NH}_{4}^{+}$.

\subsection{Treatment Creation and Application}

Treatments were provided by dissolving potassium nitrate $\left(\mathrm{KNO}_{3}\right)$, calcium nitrate [ $\mathrm{Ca}\left(\mathrm{NO}_{3}\right)_{2} \cdot \mathrm{NH}_{4} \mathrm{NO}_{3} \cdot 18 \mathrm{H}_{2} \mathrm{O}$ ], ammonium nitrate $\left(\mathrm{NH}_{4} \mathrm{NO}_{3}\right)$, magnesium nitrate $\left[\mathrm{Mg}\left(\mathrm{NO}_{3}\right)_{2} \cdot 6 \mathrm{H}_{2} \mathrm{O}\right]$, monopotassium phosphate $\left(\mathrm{KH}_{2} \mathrm{PO}_{4}\right)$, potassium sulphate $\left(\mathrm{K}_{2} \mathrm{SO}_{4}\right)$ and magnesium sulphate $\left[\mathrm{MgSO}_{4} \cdot 7 \mathrm{H}_{2} \mathrm{O}\right.$ ] into $100 \mathrm{~L}$ deionized $(\mathrm{DI}) \mathrm{H}_{2} \mathrm{O}$ in $100 \mathrm{~L}$ sealed plastic bins. The bins were cleaned and sterilized thoroughly between the different experiments to prevent any alteration in the nutrient solution due to microbial activity. One gram of micronutrient mix (Plant Prod ${ }^{\circledR}$, Bramalea, ON)/100L was added to each solution. When solutes had completely dissolved, samples were sent to Agri-Food Laboratories (Guelph, Ont., Canada) to check for accuracy.

Treatment application involved filling 1-L ceramic pots, $12 \mathrm{~cm}$ in diameter, with a nutrient solution from the marked 100-L bins. Pots were topped up as needed and were flushed out and refilled every week. Treatment samples were taken prior to weekly flushes for the measurements of EC (Hanna ${ }^{\circledR}$ Instruments HI 8733, Ann Arbor, Michigan) and pH (pH18 Aqualytic ${ }^{\circledR}$, Dortmund, North Rhine-Westphalia, Germany) levels.

\subsection{Plant Material}

Tomato (Solanum lycopersicum Mill., cv. Roma) and marigold (Tagetes erecta L., cv. Vanilla) seeds were sown 
Table 1. Ionic composition of $\mathrm{NO}_{3}^{-} / \mathrm{NH}_{4}^{+}, \mathrm{NO}_{3}^{-} / \mathrm{P}$ and $\mathrm{NH}_{4}^{+} / \mathrm{P}$ ratios $(\mathrm{mM} / \mathrm{mM})$ adjusted from a modified $1 / 2$ strength Hoagland's solution, all with an EC of $\sim 1.2 \mathrm{dS} \cdot \mathrm{m}^{-1}$.

\begin{tabular}{|c|c|c|c|c|c|c|c|}
\hline \multirow{2}{*}{ Nutrient ratio } & \multicolumn{7}{|c|}{ Ionic concentration (mM) } \\
\hline & $\mathrm{NO}_{3}^{-}$ & $\mathrm{NH}_{4}^{+}$ & $\mathrm{H}_{2} \mathrm{PO}_{4}^{-}$ & $\mathrm{K}^{+}$ & $\mathrm{Ca}^{2+}$ & $\mathrm{Mg}^{2+}$ & $\mathrm{SO}_{4}^{2-}$ \\
\hline \multicolumn{8}{|l|}{$\mathrm{NO}_{3}^{-} / \mathrm{NH}_{4}^{+}$} \\
\hline 1.83 & 5.50 & 3.00 & 0.50 & 2.00 & 1.50 & 1.00 & 2.00 \\
\hline 2.40 & 6.00 & 2.50 & 0.50 & 2.25 & 1.63 & 1.00 & 1.75 \\
\hline 3.25 & 6.50 & 2.00 & 0.50 & 3.00 & 1.75 & 1.00 & 1.50 \\
\hline 4.67 & 7.00 & 1.50 & 0.50 & 2.75 & 1.88 & 1.00 & 1.25 \\
\hline $7.50^{\mathrm{a}}$ & 7.50 & 1.00 & 0.50 & 3.00 & 2.00 & 1.00 & 1.00 \\
\hline 16.00 & 8.00 & 0.50 & 0.50 & 3.25 & 2.13 & 1.00 & 0.75 \\
\hline$\infty$ & 8.50 & 0.00 & 0.50 & 3.50 & 2.25 & 1.00 & 0.50 \\
\hline \multicolumn{8}{|l|}{$\mathrm{NO}_{3}^{-} / \mathrm{H}_{2} \mathrm{PO}_{4}^{-}$} \\
\hline 10.00 & 7.50 & 1.00 & 0.75 & 3.00 & 2.00 & 1.00 & 0.88 \\
\hline $15.00^{\mathrm{a}}$ & 7.50 & 1.00 & 0.50 & 3.00 & 2.00 & 1.00 & 1.00 \\
\hline 20.00 & 7.50 & 1.00 & 0.38 & 3.00 & 2.00 & 1.00 & 1.06 \\
\hline 30.00 & 7.50 & 1.00 & 0.25 & 3.00 & 2.00 & 1.00 & 1.13 \\
\hline 60.00 & 7.50 & 1.00 & 0.13 & 3.00 & 2.00 & 1.00 & 1.19 \\
\hline 12.50 & 6.25 & 1.00 & 0.50 & 3.00 & 2.00 & 1.00 & 1.63 \\
\hline 17.50 & 8.75 & 1.00 & 0.50 & 3.00 & 2.00 & 1.00 & 0.38 \\
\hline \multicolumn{8}{|l|}{$\mathrm{NH}_{4}^{+} / \mathrm{H}_{2} \mathrm{PO}_{4}^{-}$} \\
\hline 1.00 & 8.00 & 0.50 & 0.50 & 3.50 & 2.00 & 1.00 & 0.75 \\
\hline 1.50 & 7.75 & 0.75 & 0.50 & 3.25 & 2.00 & 1.00 & 0.88 \\
\hline $2.00^{\mathrm{a}}$ & 7.50 & 1.00 & 0.50 & 3.00 & 2.00 & 1.00 & 1.00 \\
\hline 3.00 & 7.00 & 1.50 & 0.50 & 1.25 & 1.88 & 1.00 & 1.25 \\
\hline 4.00 & 6.50 & 2.00 & 0.50 & 2.50 & 1.75 & 1.00 & 1.50 \\
\hline 1.00 & 7.50 & 1.00 & 1.00 & 3.00 & 2.00 & 1.00 & 0.75 \\
\hline 1.50 & 7.50 & 1.00 & 0.67 & 3.00 & 2.00 & 1.00 & 0.92 \\
\hline 3.00 & 7.50 & 1.00 & 0.34 & 3.00 & 2.00 & 1.00 & 1.08 \\
\hline 4.00 & 7.50 & 1.00 & 0.25 & 3.00 & 2.00 & 1.00 & 1.13 \\
\hline
\end{tabular}

${ }^{\mathrm{a}}$ Modified 1/2 strength Hoagland's solution served as a control.

in 200-cell rockwool plug trays that had been soaked in DI water, and then covered with a thin layer of finegrained vermiculite. Sunflowers (Helianthus annuus L., cv. Sunrich Orange) were also used in the second objective, but were sown in standard plastic 200-cell plug trays containing Sunshine ${ }^{\circledR}$ Professional Growing Mix LP5 (SunGro Horticulture Canada Ltd., BC, Canada), covered with fine-grained vermiculite, and germinated in a 
plastic misting chamber inside a glass greenhouse. The reason for using a growing mix was due to the lack of germination in the rockwool plugs. After germination, seedlings were hardened off gradually over a 1 week period before transplantation into a hydroponic system. Planting was done twice for each crop.

\subsection{Transplanting into Hydroponics}

Seedlings were transplanted into a hydroponic system roughly 11 days after initial seeding for sunflowers and 22 days after seeding for both marigolds and tomatoes. Transplanting involved inserting roots, still attached to either rockwool or growing mix, into a tapered hole of roughly $3.5 \mathrm{~cm}$ in diameter at the center of a styrofoam disk. Disks were approximately $10.5 \mathrm{~cm}$ in diameter and $2.5 \mathrm{~cm}$ thick. Each disk was stabilized on top of a pot with a piece of tubing.

\subsection{Bench Setup}

Pots were spaced roughly $20 \mathrm{~cm}$ apart center to center and were arranged with six plants per row across the bench. Benches were divided into 2 equal halves, each made up of a complete set of treatments and each row of 3 plants was allocated to one treatment (experimental unit). To aerate the solutions, compressed air was provided, and regulated to $500-1000 \mathrm{kPa}$. Air was distributed to each pot through additional networks of 3 air lines, which ran between 2 rows. Each pot was aerated by a smaller tube, which was placed into each pot 4 days after transplanting to aerate the solutions.

\subsection{Greenhouse Setup}

All experiments were conducted in a $100 \mathrm{~m}^{2}$ glass greenhouse at the University of Guelph, Guelph, Ont., Canada, from April 2010 to November 2012. The greenhouse had top vents, in addition to cooling with water chillers when temperatures exceeded $22^{\circ} \mathrm{C}$ and heated when temperatures dropped below $20^{\circ} \mathrm{C}$. A shade curtain was set to open entirely when outside light levels were less than $500 \mathrm{~W} \cdot \mathrm{m}^{-2}$ and to close when outside light levels surpassed $700 \mathrm{~W} \cdot \mathrm{m}^{-2}$. No artificial sources of light or $\mathrm{CO}_{2}$ were used.

\subsection{Evaluation}

Data were collected on 2 plants per experimental unit when the plants flowered (6 weeks after transplanting), as the plant at the outside of the bench was considered guard plant. Plant height, as well as root and shoot weight were recorded. Shoot dry weight refers to the dry weight of all plant parts above the styrofoam plate. Plants were dried for 3 weeks in a drying room $\left(\right.$ at $45^{\circ} \mathrm{C}$ ) before root and shoot dry weights were determined.

\subsection{Statistical Analysis}

A Type I error rate of $\alpha=0.05$ was used in all statistical analyses. The experimental set-up used a randomized complete block design with 2 plants per treatment per block and replicated once over time (season). The results of the 2 plants from each block were averaged before analysis. Data were analyzed using a mixed factorial model (MixedProc of SAS ${ }^{\circledR}$ version 9.3, SAS Institute Inc., Cary, N.C.) with a Tukey’s method for multiple comparisons. The sources of variance accounted for in the first objective were nutrient ratios, blocks, replications, and the interactions between these factors. A $2 \times 2$ treatment design was used in the second objective, with EC as an added source of variation. Regression analysis was performed between nutrient ratios and dependent variables, and the REG procedure was used to generate an equation of the trend.

\section{Results}

\section{1. $\mathrm{NO}_{3}^{-} / \mathrm{NH}_{4}^{+}$}

Marigold height increased linearly with increasing $\mathrm{NO}_{3}^{-} / \mathrm{NH}_{4}^{+}$ratios in Spring 2010 (Table 2) but not in Summer 2010 (data not shown).

For tomato, $\mathrm{NO}_{3}^{-} / \mathrm{NH}_{4}^{+}$ratios did not affect plant height in Spring (Table 2) or Summer 2010 (data not shown) but did affect shoot weight in Spring 2010 (Table 2), as shoots at a $\mathrm{NO}_{3}^{-} / \mathrm{NH}_{4}^{+}$ratio of 16 were heavier (+31\%) than those at a ratio of 2.4 . 
Table 2. Height (cm) and shoot dry weight (g) of marigold and tomato plants at flowering (Spring, 2010) in nutrient solutions with varying $\mathrm{NO}_{3}^{-} / \mathrm{NH}_{4}^{+} \quad(\mathrm{mM} / \mathrm{mM})$ ratios at an $\mathrm{EC}$ of $\sim 1.2 \mathrm{dS} \cdot \mathrm{m}^{-1}$.

\begin{tabular}{|c|c|c|c|c|}
\hline \multirow[b]{2}{*}{$\mathrm{NO}_{3}^{-} / \mathrm{NH}_{4}^{+}$ratio } & \multicolumn{2}{|c|}{ Marigold } & \multicolumn{2}{|c|}{ Tomato } \\
\hline & Height & Shoot weight & Height & Shoot weight \\
\hline 1.83 & 22.7 & 8.5 & 21.6 & $3.7 \mathrm{ab}^{\mathrm{a}}$ \\
\hline 2.40 & 24.3 & 9.2 & 23.9 & $3.5 b$ \\
\hline 3.25 & 23.9 & 8.7 & 22.7 & 3.7ab \\
\hline 4.67 & 25.3 & 9.8 & 22.8 & $4.4 \mathrm{ab}$ \\
\hline $7.50^{\mathrm{b}}$ & 24.2 & 9.0 & 25.2 & $3.9 \mathrm{ab}$ \\
\hline 16.00 & 26.8 & 9.1 & 21.9 & $4.6 \mathrm{a}$ \\
\hline$\infty$ & 25.1 & 9.5 & $N^{c}$ & NA \\
\hline $\mathrm{se}^{\mathrm{d}}$ & 0.75 & 1.27 & 1.23 & 0.19 \\
\hline $\operatorname{Pr}>F$ & 0.038 & 0.121 & 0.0529 & 0.021 \\
\hline Regression $^{\mathrm{e}}$ & $+\mathrm{L}$ & NS & NS & NS \\
\hline
\end{tabular}

${ }^{\mathrm{a}}$ Means followed by the same letter(s) within a column are not significantly different at $P \leq 0.05 .{ }^{\mathrm{b}}$ Control. ${ }^{\mathrm{c}} \mathrm{NA}=$ Not available. ${ }^{\mathrm{d}}$ Standard error (se) with $\mathrm{n}=2 .{ }^{{ }}+\mathrm{L}=$ positive linear response at $P \leq 0.05 ; \mathrm{NS}=$ non-significant.

Increasing EC caused shorter marigolds in $\mathrm{NO}_{3}^{-} / \mathrm{NH}_{4}^{+}$experiments (Figure 1(A)); while shoot weight was not affected. EC modifications using various $\mathrm{NO}_{3}^{-} / \mathrm{NH}_{4}^{+}$ratios did not affect tomato or sunflower height or shoot weight (data not shown).

\section{2. $\mathrm{NO}_{3}^{-} / \mathrm{P}$}

Marigold height decreased as $\mathrm{NO}_{3}^{-} / \mathrm{P}$ ratio increased in the first replication (Spring, 2010; Table 3). Shoots of marigolds supplied with the highest $\mathrm{NO}_{3}^{-} / \mathrm{P}$ ratio of 60 weighed significantly less than those supplied with any other $\mathrm{NO}_{3}^{-} / \mathrm{P}$ treatment, including the control (Table 3).

These effects were not evident in the second marigold or either tomato replication (Spring to Summer, 2010; data not shown).

Marigolds supplied with $4.0 \mathrm{dS} \cdot \mathrm{m}^{-1}$ solutions were shorter than those supplied with lower EC solutions (Figure 1(B)) using different $\mathrm{NO}_{3}^{-} / \mathrm{P}$ ratios. Marigold shoot weight was lowest when plants were supplied with $0.6 \mathrm{dS} \cdot \mathrm{m}^{-1}$ solutions (Figure 2(A)). At lower ECs $\left(0.6\right.$ and $1.2 \mathrm{dS} \cdot \mathrm{m}^{-1}$ ) shoot dry weight decreased with increasing $\mathrm{NO}_{3}^{-} / \mathrm{P}$ levels (Figure 3(A)). However, this effect was absent at higher ECs (2.2 or $4.0 \mathrm{dS} \cdot \mathrm{m}^{-1}$; data not shown).

Like marigolds, sunflowers were generally shortest at an EC of $4.0 \mathrm{dS} \cdot \mathrm{m}^{-1}$ (Figure $\mathbf{1}(\mathbf{C})$ ) in the $\mathrm{NO}_{3}^{-} / \mathrm{P}$ experiments. Sunflower height also decreased linearly with increasing $\mathrm{NO}_{3}^{-} / \mathrm{P}$ ratios at an EC of $0.6 \mathrm{dS} \cdot \mathrm{m}^{-1}$ (Figure 3(B)), but not at the higher ECs (data not shown). Sunflower shoot weight decreased linearly with increasing $\mathrm{NO}_{3}^{-} / \mathrm{P}$ ratios at ECs of 0.6 and $1.2 \mathrm{dS} \cdot \mathrm{m}^{-1}$ (Figure 3(A)) but not at the higher ECs (data not shown).

Tomatoes responded in an opposite direction to EC levels compared to marigolds and sunflowers, as tomatoes tended to be taller at higher ECs with differing $\mathrm{NO}_{3}^{-} / \mathrm{P}$ ratios (Figure $1(\mathrm{D})$ ). Tomato shoots weighed the least at an EC of $0.6 \mathrm{dS} \cdot \mathrm{m}^{-1}$ compared with the higher EC levels (Figure 2(B)). Shoot weight decreased linearly as ratio increased, but only at the lowest EC of $0.6 \mathrm{dS} \cdot \mathrm{m}^{-1}$ (Figure $3(\mathrm{C})$ ).

\section{3. $\mathrm{NH}_{4}^{+} / \mathrm{P}$}

Modifications in $\mathrm{NH}_{4}{ }^{+} / \mathrm{P}$ ratios had no significant effect on plant height at an EC of $1.2 \mathrm{dS} \cdot \mathrm{m}^{-1}$ (data not shown). However, marigolds were generally shorter at higher ECs using these ratios (Figure 1(E)). Dry shoot weight of marigolds at ECs of 0.6 and $4.0 \mathrm{dS} \cdot \mathrm{m}^{-1}$ weighed less than shoots from 1.2 or $2.2 \mathrm{dS} \cdot \mathrm{m}^{-1}$ (Figure 2(C)). A similar trend was found for tomato shoot dry weight (Figure 2(D)) and sunflower shoot dry weight (Figure 2(E)). Sunflower height was not affected by EC level, but by $\mathrm{NH}_{4}^{+} / \mathrm{P}$ ratio alone (Table 4). The tallest plants were obtained at a $\mathrm{NH}_{4}^{+} / \mathrm{P}$ ratio of 3.0 , and the shortest at a $\mathrm{NH}_{4}^{+} / \mathrm{P}$ ratio of $4.0\left(1.00 \mathrm{mM} \mathrm{NH}_{4}^{+} / 0.25 \mathrm{mM}\right.$ $\mathrm{H}_{2} \mathrm{PO}_{4}^{-}$). 


\section{C-Sunflower \\ $\mathrm{NO}_{3}{ }^{-} / \mathrm{P}$}

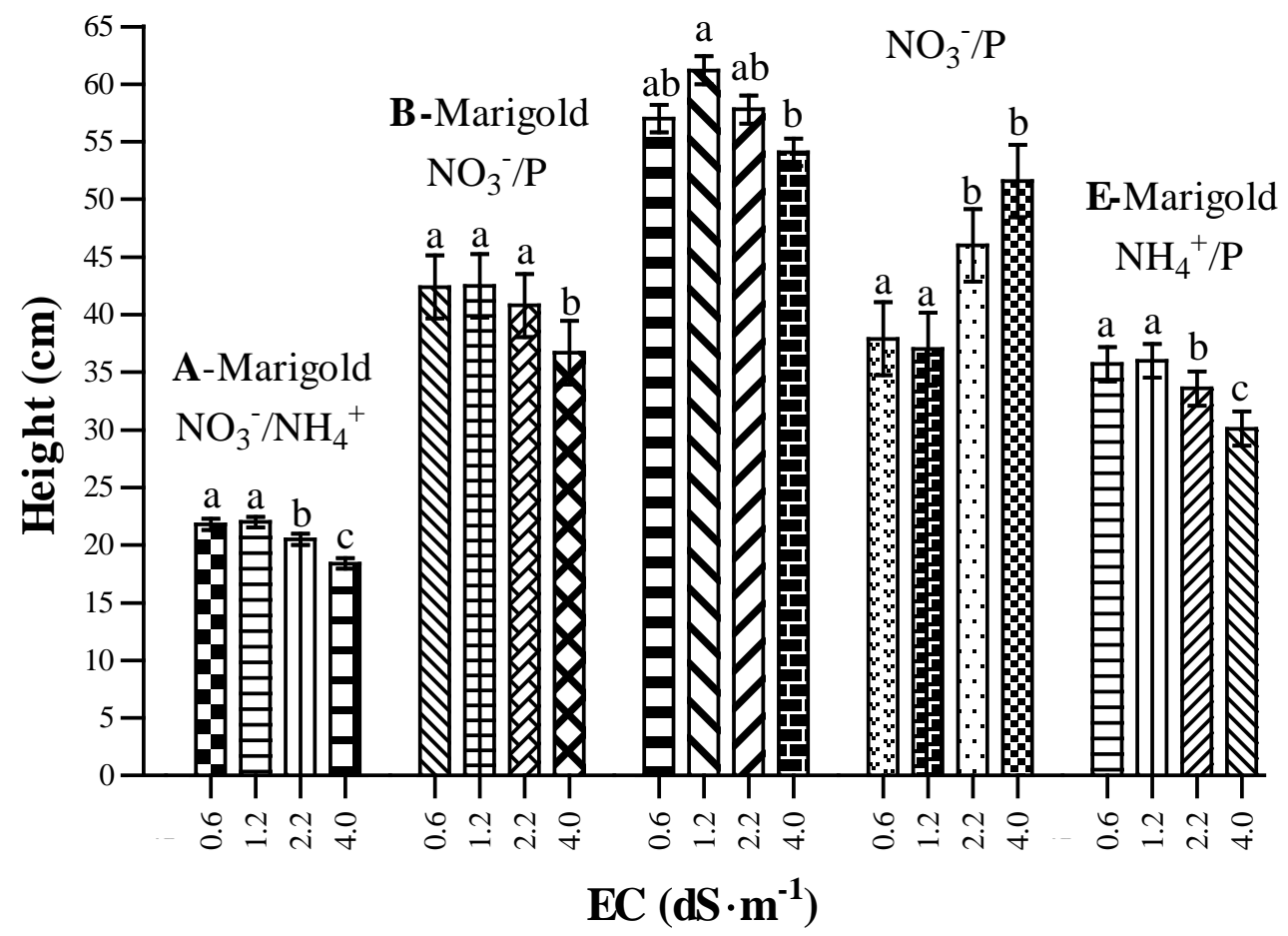

Figure 1. The effect of electrical conductivity (EC) of nutrient solutions on mean height \pm se using different $\mathrm{NO}_{3}^{-} / \mathrm{NH}_{4}^{+} \quad \mathrm{ra}^{-}$ tios (mM/mM) for marigold (A-Winter and Spring, 2011); or using different $\mathrm{NO}_{3}^{-} / \mathrm{P}$ ratios for marigold (B-Summer 2011), sunflower (C—Summer 2011) and tomato (D-Summer 2011); or using different $\mathrm{NH}_{4}^{+} / \mathrm{P}$ ratios for marigold (E-Summer 2012). Data represent means from 5 ratios, 2 blocks and 2 seasons; $n=20$. The following ratios were used (mM/mM): 10, 15, 20, 30 and 60 for $\mathrm{NO}_{3}^{-} / \mathrm{P} ; 1,1.5,2.0,3.0$ and 4.0 for $\mathrm{NH}_{4}^{+} / \mathrm{P}$ and 3.25, 4.7, 7.5, 16.0 and $\infty$ for $\mathrm{NO}_{3}^{-} / \mathrm{NH}_{4}^{+}$. Different letter(s) above error bars within one species/ratio grouping denote significant difference at $\mathrm{P} \leq 0.05$.

Table 3. Marigold height $(\mathrm{cm})$ and shoot dry weight $(\mathrm{g})$ at flowering (Spring, 2010) in nutrient solutions with varying $\mathrm{NO}_{3}^{-}$ $/ \mathrm{P}$ ratios $(\mathrm{mM} / \mathrm{mM})$ at an $\mathrm{EC}$ of $\sim 1.2 \mathrm{dS} \cdot \mathrm{m}^{-1}$.

\begin{tabular}{ccc}
\hline $\mathrm{NO}_{3}^{-} / \mathrm{H}_{2} \mathrm{PO}_{4}^{-}$Ratio & Height & Shoot Weight \\
10.0 & 24.3 & $9.7 \mathrm{a}^{\mathrm{a}}$ \\
12.5 & 23.4 & $8.9 \mathrm{a}$ \\
$15.0^{\mathrm{b}}$ & 24.2 & $9.0 \mathrm{a}$ \\
17.5 & 25.3 & $9.5 \mathrm{a}$ \\
20.0 & 23.0 & $8.8 \mathrm{a}$ \\
30.0 & 24.8 & $9.2 \mathrm{a}$ \\
60.0 & 22.4 & $5.6 \mathrm{~b}$ \\
$\mathrm{se}^{\mathrm{c}}$ & 0.67 & 0.87 \\
$\operatorname{Pr}^{>} \mathrm{F}^{\mathrm{R}}$ & 0.042 & 0.0002 \\
\hline
\end{tabular}

${ }^{\mathrm{a}}$ Means followed by the same letter within a column are not significantly different at $\mathrm{P} \leq 0.05$. ${ }^{\mathrm{b}}$ Control. ${ }^{\mathrm{c}}$ Standard error (se) with $\mathrm{n}=2 .{ }^{\mathrm{d}}-\mathrm{L}=$ negative linear response at $\mathrm{P} \leq 0.05 ; \mathrm{NS}=$ non-significant. 


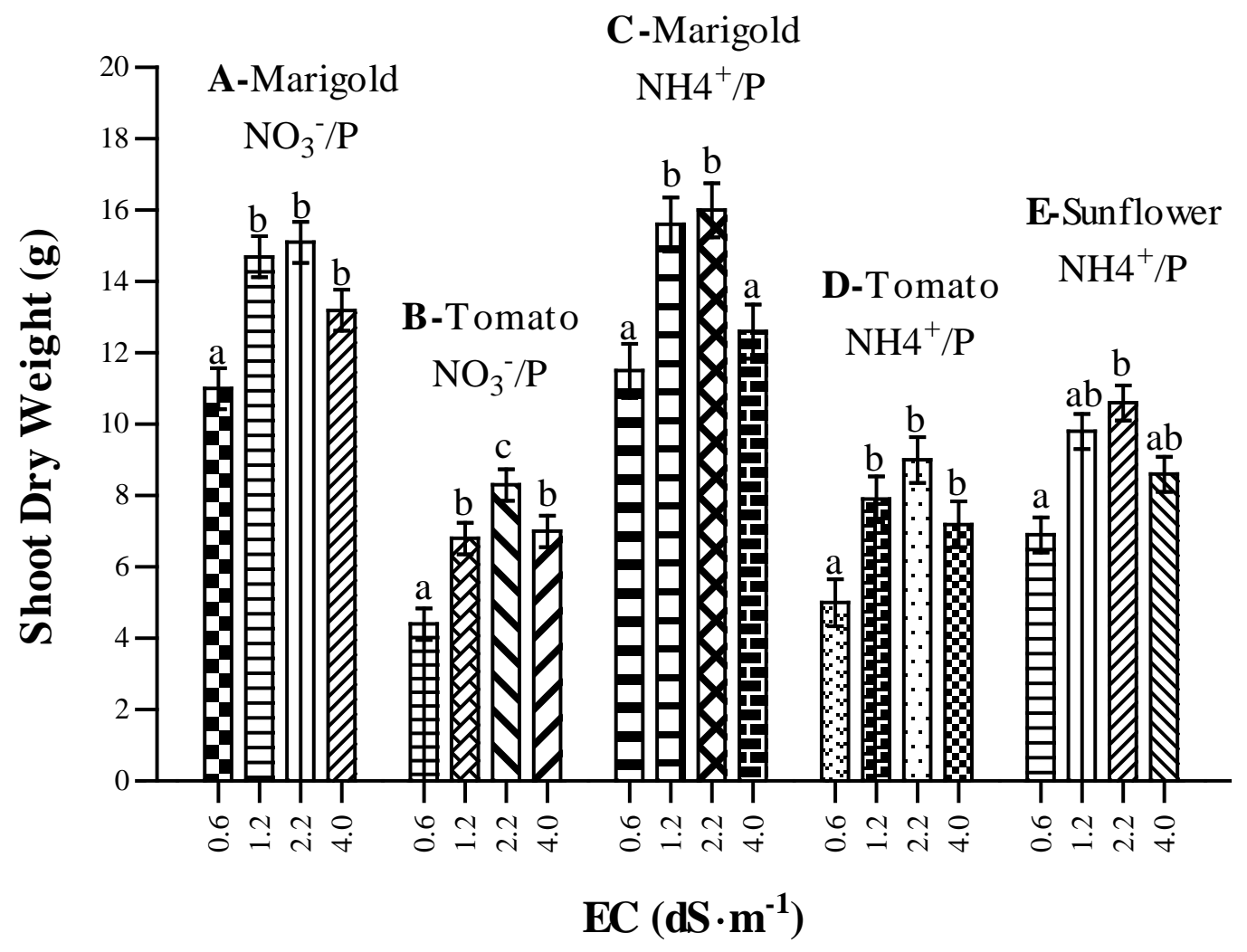

Figure 2. The effect of electrical conductivity (EC) on mean shoot dry weight \pm se using different $\mathrm{NO}_{3}^{-} / \mathrm{P}$ ratios for marigold (A-Summer 2011) and tomato (B-Summer 2011); or using different $\mathrm{NH}_{4}^{+} / \mathrm{P}$ ratios for marigold (C-Summer, 2012), tomato (D-Spring and Summer 2012) and sunflower (E-Spring and Summer 2012). Data represent means from 5 ratios, 2 blocks and 2 seasons; $\mathrm{n}=20$. The following ratios were used $(\mathrm{mM} / \mathrm{mM}): 10,15,20,30$ and 60 for $\mathrm{NO}_{3}^{-} / \mathrm{P} ; 1,1.5$, 2.0, 3.0 and 4.0 for $\mathrm{NH}_{4}^{+} / \mathrm{P}$. Different letter(s) above error bars within one species/ratio grouping denote significant difference at $\mathrm{P} \leq 0.05$.

Table 4. Sunflower height $(\mathrm{cm})$ at flowering (Spring and Summer, 2012) in nutrient solutions with varying $\mathrm{NH}_{4}^{+} / \mathrm{P}$ ratios $(\mathrm{mM} / \mathrm{mM})$ at ECs of $0.6,1.2,2.2$ and $4.0 \mathrm{dS} \cdot \mathrm{cm}^{-1}$.

$\begin{array}{cc}\mathrm{NO}_{3}^{-} / \mathrm{H}_{2} \mathrm{PO}_{4}^{-} \text {Ratio } & \text { Height }^{\mathrm{a}} \\ 1.0 & 66.1 \mathrm{bc} \mathrm{c}^{\mathrm{b}} \\ 1.5 & 69.3^{\mathrm{abc}} \\ 2.0^{\mathrm{c}} & 69.5^{\mathrm{ab}} \\ 3.0 & 70.2^{\mathrm{a}} \\ 4.0(2.0 / 0.5) & 67.4^{\mathrm{abc}} \\ 4.0(1.0 / 0.25) & 65.4^{\mathrm{c}} \\ \mathrm{se}^{\mathrm{d}} & 1.75 \\ \operatorname{Pr}>\mathrm{F} & 0.001\end{array}$

${ }^{a}$ The results of the different EC's were combined as there was no statistical differences between the EC levels. ${ }^{b}$ Means followed by the same letter(s) within a column are not significantly different at $\mathrm{P} \leq 0.05$. ${ }^{\mathrm{c}}$ Control. ${ }^{\mathrm{d}}$ Standard error (se) with $\mathrm{n}=16$. 

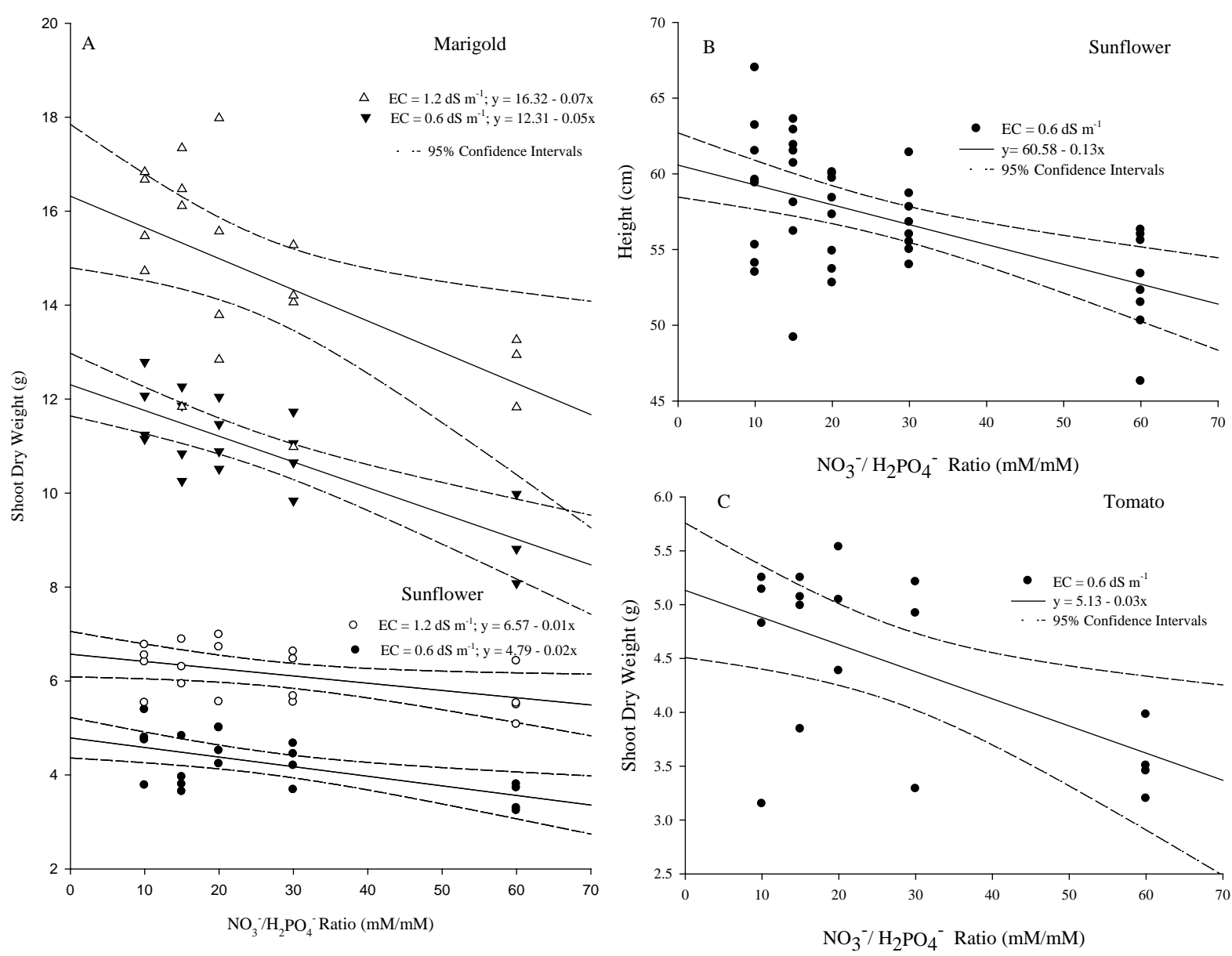

Figure 3. The effect of $\mathrm{NO}_{3}^{-} / \mathrm{P}$ ratio $(\mathrm{mM} / \mathrm{mM})$ of nutrient solutions on shoot dry weight $(\mathrm{g})$ using EC's of 0.6 and 1.2 $\mathrm{dS} \cdot \mathrm{m}^{-1}$ for marigold $\left(\mathrm{A}-\mathrm{R}^{2}=0.62\right)$ and sunflower $\left(\mathrm{A}-\mathrm{R}^{2}=0.24\right)$; or height $(\mathrm{g})$ using an $\mathrm{EC}$ of $0.6 \mathrm{dS} \cdot \mathrm{m}^{-1}$ for sunflower $\left(B-R^{2}=0.30\right)$; or shoot dry weight using an $E C$ of $0.6 \mathrm{dS} \cdot \mathrm{m}^{-1}$ for tomato $\left(C-\mathrm{R}^{2}=0.33\right)$. Data represent means from 2 blocks and 2 seasons; $\mathrm{n}=4$.

\subsection{Solution EC/pH}

The results of the $\mathrm{EC}$ and $\mathrm{pH}$ measurements at the beginning of each week showed that the $\mathrm{pH}$ decreased with increased EC (Table 5). The $\mathrm{pH}$ at EC $=4.0 \mathrm{dS} / \mathrm{m}$ was about $1.1 \mathrm{pH}$ unit lower for $\mathrm{NO}_{3}^{-} / \mathrm{NH}_{4}^{+}$and $\mathrm{NO}_{3}^{-} / \mathrm{P}$ ratios and about $0.4 \mathrm{pH}$ unit for $\mathrm{NH}_{4}^{+} / \mathrm{P}$ ratios compared to solutions at $\mathrm{EC}=0.6 \mathrm{dS} / \mathrm{m}$. The results at the end of each week showed that at low EC (0.6 and $1.2 \mathrm{dS} / \mathrm{m})$, the EC decreased, but increased when the EC was 2.2 and $4.0 \mathrm{dS} / \mathrm{m}$ compared to the initial EC for all crops. The weekly change in $\mathrm{pH}$ showed an increase at initial low, while it increased at the higher EC levels $(2.2$ and $4.0 \mathrm{mS} / \mathrm{cm})$ for all three ratios of $\mathrm{NO}_{3}^{-} / \mathrm{NH}_{4}^{+}, \mathrm{NO}_{3}^{-} / \mathrm{P}$ and $\mathrm{NH}_{4}^{+} / \mathrm{P}$ and/or species.

\section{Discussion}

Growers generally believe that plant height can be controlled by increasing $\mathrm{NO}_{3}^{-} / \mathrm{NH}_{4}^{+}$ratio. In this study, $\mathrm{NO}_{3}^{-} / \mathrm{NH}_{4}^{+}$ratio did not reliably affect plant height or shoot weight. Nelson [10] hypothesized that the industrial misconception that $\mathrm{NO}_{3}^{-} / \mathrm{NH}_{4}^{+}$ratio affects plant height may be attributable to the low $\mathrm{P}$ concentrations present in high $\mathrm{NO}_{3}^{-}$fertilizers.

Studies suggest that low $\mathrm{P}$ concentrations [7] or high N/P ratios [8] may limit plant height. The $\mathrm{NO}_{3}^{-} / \mathrm{P}$ ratios used in this study did not reliably limit plant height, but reduced shoot weight in all species, especially at a combination of low EC and high $\mathrm{NO}_{3}^{-} / \mathrm{P}$ ratio (Figure 3), suggesting that growth restricting responses were the re- 
Table 5. Mean change in EC $\left(\mathrm{dS} \cdot \mathrm{m}^{-1}\right)$ and $\mathrm{pH}$ over one week periods (6) for different species during the growth from transplanting to flowering. Solution was flushed and refilled with fresh solutions on a weekly basis. $\mathrm{N}=12$ (6 weeks and 2 replications).

\begin{tabular}{|c|c|c|c|c|c|c|c|c|}
\hline \multirow[b]{2}{*}{ Ratio } & \multirow[b]{2}{*}{$\mathbf{E C}^{\mathrm{a}}$} & \multirow[b]{2}{*}{$\mathbf{p H}^{\mathrm{b}}$} & \multicolumn{3}{|c|}{ Mean change in $\mathrm{EC}^{\mathrm{C}}\left(\mathrm{dS} \cdot \mathrm{m}^{-1}\right)$} & \multicolumn{3}{|c|}{ Mean change in $\mathbf{p H}^{\mathrm{d}}$} \\
\hline & & & Marigolds & Sunflowers & Tomatoes & Marigolds & Sunflowers & Tomatoes \\
\hline \multicolumn{9}{|c|}{$\mathrm{NO}_{3}^{-} / \mathrm{NH}_{4}^{+} \mathrm{e}$} \\
\hline & 0.6 & 5.7 & -0.3 & -0.4 & -0.2 & +0.2 & +2.8 & +0.1 \\
\hline & 1.2 & 5.3 & -0.1 & -0.4 & +0.3 & +1.6 & +1.1 & +0.4 \\
\hline & 2.2 & 4.9 & +1.4 & +1.2 & +1.3 & -0.5 & -0.9 & +0.1 \\
\hline & 4.0 & 4.6 & +3.5 & +3.3 & +2.7 & -0.7 & -1.2 & -0.3 \\
\hline \multicolumn{9}{|c|}{$\mathrm{NO}_{3}^{-} / \mathrm{P}^{\mathrm{e}}$} \\
\hline & 0.6 & 5.7 & -0.3 & -0.2 & -0.4 & +0.6 & -0.3 & +1.2 \\
\hline & 1.2 & 5.5 & -0.1 & -0.1 & -0.4 & +1.1 & +0.3 & +1.1 \\
\hline & 2.2 & 5.3 & +1.5 & +1.4 & +0.8 & +1.2 & -0.9 & +0.4 \\
\hline & 4.0 & 4.5 & +3.5 & +2.8 & +2.9 & -0.6 & -0.6 & -0.3 \\
\hline \multicolumn{9}{|c|}{$\mathrm{NH}_{4}^{+} / \mathrm{P}^{\mathrm{e}}$} \\
\hline & 0.6 & 5.4 & -0.3 & -0.2 & -0.1 & +0.1 & +1.0 & +0.8 \\
\hline & 1.2 & 5.4 & 0.0 & -0.1 & +0.2 & +1.1 & +1.2 & +0.8 \\
\hline & 2.2 & 5.2 & +1.3 & +1.2 & +1.5 & -0.6 & -0.4 & -1.5 \\
\hline & 4.0 & 5.0 & +1.5 & +2.9 & +3.1 & -1.0 & -1.1 & -0.3 \\
\hline
\end{tabular}

${ }^{\mathrm{a}}$ Initial EC values at the beginning of each week; ${ }^{\mathrm{b}}$ Initial $\mathrm{pH}$ values at the beginning of each week; ${ }^{\mathrm{c}} \mathrm{Change}$ from initial EC value over the course of one week; $(+)$ denotes increase in value, $(-)$ denotes decrease in value; ${ }^{\mathrm{d}}$ Change from initial $\mathrm{pH}$ value over the course of one week; $(+)$ denotes increase in value, $(-)$ denotes decrease in value; ${ }^{\mathrm{e}}$ The ratios $(\mathrm{mM} / \mathrm{mM})$ for $\mathrm{NO}_{3}^{-} / \mathrm{NH}_{4}^{+}$were $3.25,4.7,7.5,16.0$ and $\infty$; for $\mathrm{NO}_{3}^{-} / \mathrm{P}_{\text {were }} 10,15,20$, 30 and 60; and for $\mathrm{NH}_{4}^{+} / \mathrm{P} 1.0,1.5,2.0,3.0$ and 4.0.

sult of absolute $\mathrm{P}$ concentration, rather than $\mathrm{N} / \mathrm{P}$ ratio. At ECs of 0.6 and $1.2 \mathrm{dS} \cdot \mathrm{m}^{-1}$, a $\mathrm{NO}_{3}^{-} / \mathrm{P}$ ratio of 60 provided 0.06 and $0.13 \mathrm{Mm} \mathrm{H}_{2} \mathrm{PO}_{4}^{-}$respectively; higher concentrations than that used by Kavanova [7] to limit grass leaf elongation $\left(0.02 \mathrm{mM} \mathrm{H} \mathrm{H}_{2} \mathrm{PO}_{4}^{-}\right)$. $\mathrm{NH}_{4}^{-} / \mathrm{P}$ ratio effects were absent (tomatoes and marigolds; data not shown) or small for sunflowers (Table 4), likely because the lowest $\mathrm{H}_{2} \mathrm{PO}_{4}^{-}$concentration for this set of ratios was $0.13 \mathrm{mM} \mathrm{H}_{2} \mathrm{PO}_{4}^{-}$.

The effects of all three ratios $\left(\mathrm{NO}_{3}^{-} / \mathrm{NH}_{4}^{+}, \mathrm{NO}_{3}^{-} / \mathrm{P}\right.$ and $\left.\mathrm{NH}_{4}^{-} / \mathrm{P}\right)$ varied mostly during Spring. No ratio effects were observed during Fall or Winter months, when plant growth was generally reduced. This observation would require more study.

High EC levels consistently produced the shortest marigold and sunflower plants for all three ratios. The exception was tomato, which increased in height with increasing EC using different $\mathrm{NO}_{3}^{-} / \mathrm{P}$ ratios. Alternately, EC effected shoot weight similarly for all species (Figures 2(A)-(E)). Plants grown at an EC of $0.6 \mathrm{dS} \cdot \mathrm{m}^{-1}$ generally weighed the least, followed by those at an EC of $4.0 \mathrm{dS} \cdot \mathrm{m}^{-1}$. Unlike ratio modifications, EC effects were not dependent on season.

These studies were conducted using hydroponic solutions in order to eliminate possible effects of matrix potential or interactions with the cation exchange capacity of soil and/or organic matter. However there were changes of the EC and $\mathrm{pH}$ due to differential uptake of nutrients and/or water by the plants over time compared to the original solutions. Effort was taken to change the solution on a weekly basis to compensate for this. However, despite the effects from differential uptake of cations, anions and concentration of ions, macronutrient modification, at the ratios evaluated in this study, would not be a viable means for plant height control in a hydroponic nutrient solution. 


\section{Conclusion}

Contrary to industrial beliefs, plant height was not reliably affected by $\mathrm{NO}_{3}^{-} / \mathrm{NH}_{4}^{+}$ratio modification. P limitation (high $\mathrm{NO}_{3}^{-} / \mathrm{P}$ ratios) more consistently resulted in decreased shoot weight rather than plant height. $\mathrm{P}$ concentrations lower than those used in this hydroponic study $\left(<0.06 \mathrm{mM} \mathrm{H}_{2} \mathrm{PO}_{4}^{-}\right)$may be required to achieve more consistent height control. Our results show that plant height control, depending on species, may be better attained through increasing EC levels rather than nutrient modification alone.

\section{Acknowledgements}

This research project was financially supported by Flowers Canada (Ontario) and the Canadian Ornamental Horticulture Research and Innovation Cluster.

\section{References}

[1] Erwin, J.E., Heins, R.D. and Karlsson, M.G. (1989) Thermomorphogenesis in Lilium longiflorum. American Journal of Botany, 76, 47-52. http://dx.doi.org/10.2307/2444772

[2] Grimstad, S.O. (1993) The Effect of a Daily Low Temperature Pulse on Growth and Development of Greenhouse Cucumber and Tomato Plants during Propagation. Scientia Horticulturae, 53, 53-62. http://dx.doi.org/10.1016/0304-4238(93)90137-F

[3] Moe, R., Heins, R.D. and Erwin, J. (1991) Stem Elongation and Flowering of the Long-Day Plant Campanula isophylla Moretti in Response to Day and Night Temperature Alternations and Light Quality. Scientia Horticulturae, 48, 141151. http://dx.doi.org/10.1016/0304-4238(91)90161-Q

[4] Blom, T.J., Tsujita, M.J. and Roberts, G.L. (1995) Far-Red at End of Day and Reduced Irradiance Affect Plant Height of Easter and Asiatic Hybrid Lilies. HortScience, 30, 1009-1012.

[5] Rideout, J.W. (2004) Field Growth and Yield of Tomato Transplants Grown in the Float System Using Low Phosphorous Fertilizer and Height Restricting Cultural Practices. HortScience, 39, 23-27.

[6] Gislerod, H.R. and Mortensen, L.M. (1990) Relative Humidity and Nutrient Concentration Affect Nutrient Uptake and Growth of Begonia $\times$ Hiemalis. HortScience, 25, 524-526.

[7] Kavanova, M., Lattanzi, F.A., Grimoldi, A. and Schnyder, H. (2006) Phosphorous Deficiency Decreases Cell Division and Elongation In Grass Leaves. Plant Physiology, 141, 766-775. http://dx.doi.org/10.1104/pp.106.079699

[8] Rideout, J.W. and Overstreet, L.F. (2003) Phosphorous Rate in Combination with Cultural Practices Reduces Excessive Growth of Tomato Seedlings in the Float System. HortScience, 38, 524-528.

[9] González-García, J.L., Rodríguez-Mendoza, M.N., Sánchez-García, P., Osorio-Rosales, B., Trejo-Téllez, L.I., Alcántar-'González, G. and Sandoval-Villa, M. (2009) Ammonium/nitrate Ratios in Hydroponic Production of Aromatic Herbs. Acta Horticulturae, 843, 123-128. http://dx.doi.org/10.17660/ActaHortic.2009.843.14

[10] Nelson, P.V., Song, C., Huang, J., Niedziela, C.E. and Swallow, W.S. (2012) Relative Effects of Fertilizer Nitrogen and Phosphate Level on Control of Bedding Plant Seedling Growth. HortScience, 47, 249-253.

[11] Dumbroff, E.B. and Cooper, A.W. (1974) Effects of Salt Stress Applied in Balanced Nutrient Solutions at Several Stages during Growth of Tomato. Botanical Gazette, 135, 219-224. http://dx.doi.org/10.1086/336755

[12] Tavakkoli, E., Rengasamy, P. and McDonald, G.K. (2010) The Response of Barley to Salinity Stress Differs between Hydroponic and Soil Systems. Functional Plant Biology, 37, 621-633. http://dx.doi.org/10.1071/FP09202

[13] Judd, L.K. and Cox, D.A. (1992) Growth of New Guinea Impatiens Inhibited by High Growth-Medium Electrical Conductivity. HortScience, 27, 1193-1194.

[14] Hoagland, D.R. and Arnon, D.I. (1950) The Water-Culture Method for Growing Plants without Soil. California Agricultural Experiment Station, Circular-347. 


\section{Submit or recommend next manuscript to SCIRP and we will provide best service for you:}

Accepting pre-submission inquiries through Email, Facebook, LinkedIn, Twitter, etc.

A wide selection of journals (inclusive of 9 subjects, more than 200 journals)

Providing 24-hour high-quality service

User-friendly online submission system

Fair and swift peer-review system

Efficient typesetting and proofreading procedure

Display of the result of downloads and visits, as well as the number of cited articles

Maximum dissemination of your research work

Submit your manuscript at: http://papersubmission.scirp.org/ 